\title{
Amyloid and Alzheimer's Disease: Inside and Out
}

\author{
Joshua H.K. Tam, Stephen H. Pasternak
}

\begin{abstract}
Alzheimer's disease (AD) is poised to become the most serious healthcare issue of our generation. The leading theory of AD pathophysiology is the Amyloid Cascade Hypothesis, and clinical trials are now proceeding based on this hypothesis. Here, we review the original evidence for the Amyloid Hypothesis, which was originally focused on the extracellular deposition of beta amyloid peptides $(\mathrm{A} \beta)$ in large fibrillar aggregates, as well as how this theory has been extended in recent years to focus on highly toxic small soluble amyloid oligomers. We will also examine emerging evidence that $\mathrm{A} \beta$ may actually begin to accumulate intracellularly in lysosomes, and the role for intracellular $\mathrm{A} \beta$ and lysosomal dysfunction may play in AD pathophysiology. Finally, we will review the clinical implications of these findings.

RÉSUMÉ: Tout sur l'amyloïde et la maladie d'Alzheimer. La maladie d'Alzheimer (MA) est sur le point de devenir le problème le plus important du secteur des soins de santé de notre génération. La théorie qui prévaut concernant la physiopathologie de la MA est l'hypothèse de la cascade amylö̈de. Des essais cliniques fondés sur cette théorie sont actuellement en cours. Nous revoyons les données originales qui y ont donné lieu. Elle est centrée sur la déposition extracellulaire du peptide bêta-amyloïde $(\beta A)$ sous forme de gros amas fibrillaires. Cette théorie a été élargie au cours des dernières années aux petits oligomères amyloïdes solubles qui sont extrêmement toxiques. Nous examinons les données de plus en plus nombreuses à l'effet que la $\beta$ A pourrait commencer à s'accumuler dans les lysosomes intracellulaires et comment la $\beta$ A intracellulaire et la dysfonction lysosomiale joueraient un rôle dans la physiopathologie de la MA. Enfin, nous revoyons les implications cliniques de ces observations.
\end{abstract}

Can J Neurol Sci. 2012; 39: 286-298

\begin{abstract}
Alzheimer's disease (AD) is the most common neurodegenerative illness. The main risk factor for $\mathrm{AD}$ is age. $\mathrm{AD}$ affects about $1 \%$ of individuals at age 65 , with this rate doubling every five years, so that $30 \%$ of 80 -year-olds are affected $^{1,2}$. The Alzheimer's Society of Canada estimates that there are currently 500,000 Canadians suffering with Alzheimer's disease and this number is expected to rise to more than one million by $2038^{3}$. These numbers are mirrored in the United States and the rest of the world where there are 5.1 million and 35 million affected respectively, and these numbers are expected to grow to 15 million and 115 million by $2050^{4-6}$. Alzheimer's disease is expensive, with the cost of caring for Canadians with Alzheimer's disease estimated at $\$ 15$ billion/year now and projected to rise to a staggering $\$ 158$ billion per year by $2038^{3}$. Alzheimer's disease already costs the American economy more than US $\$ 150$ billion/year ${ }^{5}$. These estimates suggest that $\mathrm{AD}$ is poised to become a major challenge for our health care system and our society.

Alzheimer's disease is characterized by many neuropathological changes including neurofibrillary tangles, and loss of synapses and neurons, but it is amyloid plaques that distinguish Alzheimer's disease from other neurodegenerative diseases ${ }^{7}$. Although Alois Alzheimer first described this disease
\end{abstract}

more than 100 years ago, it was only in the 1980's that $\beta$ amyloid peptide $(A \beta)$ was identified as the major component of amyloid plaques. This led to the Amyloid Cascade Hypothesis, which is the current leading model of pathophysiology in Alzheimer's disease. In its initial form, the Amyloid Hypothesis posited that amyloid deposition in large macromolecular fibrils was the initiating factor for $\mathrm{AD}$, with numerous other pathological changes occurring secondarily ${ }^{8,9}$. With antiamyloid therapies in phase 3 clinical trials, it is timely to review the Amyloid Hypothesis as it was originally proposed and the new directions that it is taking. The role of amyloid in intracellular compartments will also be reviewed.

From the J. Allyn Taylor Centre for Cell Biology (JHKT, SHP), Molecular Brain Research Group, Robarts Research Institute, Department of Clinical Neurological Sciences (SHP), Department of Physiology and Pharmacology (JHKT, SHP) Schulich School of Medicine, the University of Western Ontario, London, Ontario, Canada. Received October 5, 2011. Final Revisions Submitted November 9, 2011. Correspondence to: Stephen H. Pasternak, Robarts Research Institute, 100 Perth Drive, London, Ontario, Canada, N6A 5K8. Email: spasternak@robarts.ca. 
$\mathrm{A} \beta$ is produced by the cleavage of a large transmembrane protein call the Amyloid Precursor Protein (APP) (Figure 1). First, APP is cleaved at a $\beta$-site by an aspartyl proteinase referred to as BACE (beta-site APP-cleaving enzyme) ${ }^{10-15}$. Subsequently, APP is cleaved again at a variable " $\gamma$ " cleavage site by an enzyme referred to as the $\gamma$-secretase (described below) to release peptides ranging from 38-43 amino acids. The $\gamma$ cleavage regulates the amount of $\mathrm{A} \beta$ produced, as well as the relative amount of the more toxic 42 amino acid form of $A \beta$. Amyloid precursor protein may also be cleaved at an $\alpha$ position within the $A \beta$ sequence, by an enzyme (or family of enzymes) referred to as $\alpha$-secretases, which prevents the production of $\mathrm{A} \beta^{16-18}$. $\beta$-cleavage is the preferred pathway in neurons ${ }^{19}$. Once produced, individual amyloid peptides (A $\beta 42$ in particular) have a high propensity to form aggregates that begin as small assemblies of dimers and trimers, followed by 'oligomers' and protofibrils, and the large insoluble fibrils that are seen in amyloid plaques ${ }^{20,21}$.

\section{The AMyloid Hypothesis}

The literature of AD encompasses numerous pathophysiological mechanisms (reviewed in $^{22}$ ) that often seem to be dueling for the status of "most important". Indeed the tissue loss seen in gross pathology of AD (Figure 2) is likely the result of many processes, and not merely the result of deposition of amyloid plaques (Figure 3). However, the origins of amyloid hypothesis are not rooted only in pathology, but also in genetics.

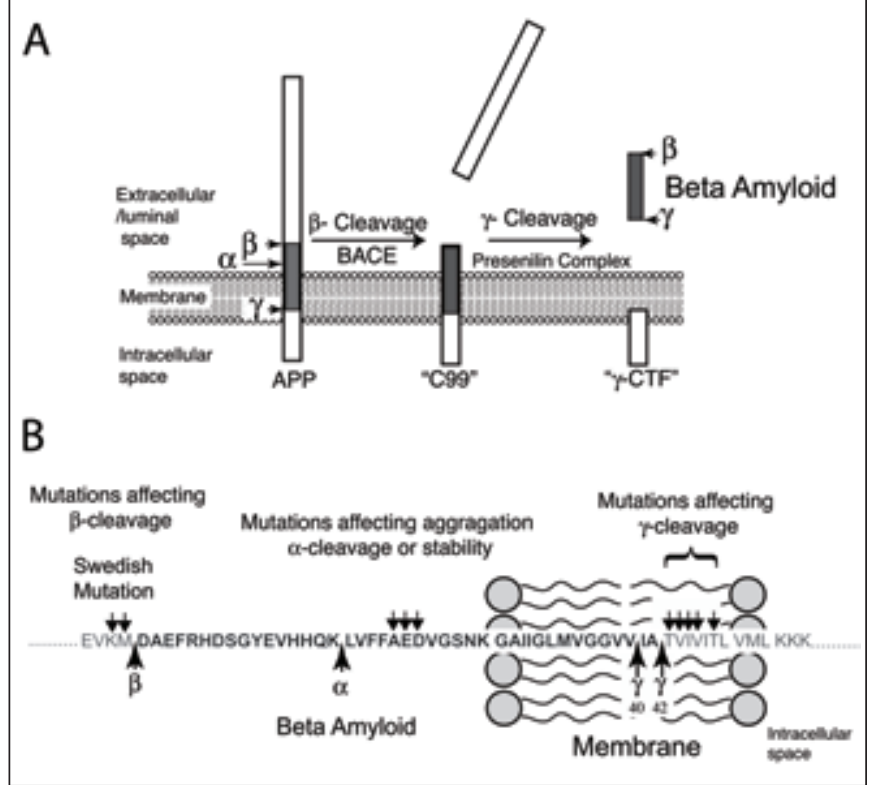

Figure 1: Schematic of beta amyloid production. A. APP is a large transmembrane protein that is cleaved first at a beta site by $B A C E$, and then at a gamma site by the gamma secretase to release $A \beta$. B. The sequence of APP spanning the $A \beta$ and transmembrane regions of APP showing the sites of the $\alpha$-, $\beta$-and $\gamma$-secretase cleavage sites. Examples of some of the sites of $A D$-causing mutations are indicated.

\section{Chromosome 21}

The genetic view of Alzheimer's disease begins with the longstanding observation that patients with Down's syndrome (Trisomy 21) invariably develop neuropathological features indistinguishable from Alzheimer's disease in early adulthood $^{23,24}$. This suggested a simple gene-dosage effect caused by an extra copy of a critical gene on chromosome 21 . The purification and sequencing of the components in vascular amyloid and amyloid plaques in 1984 lead to the discovery of $\mathrm{A} \beta^{25,26}$ and to the subsequent cloning of the APP gene on chromosome $21^{27,28}$. The cloning of APP (and subsequent Familial Alzheimer's Disease (FAD) genes below) has allowed their study in cultured cells and the generation of mouse models. In the case of APP, this led to the surprising finding that $A \beta$ production was not a rare pathological event but rather a normal process. A $\beta$ is produced by many cell types and is normally present in plasma and cerebrospinal fluid (CSF) ${ }^{29-31}$. Synaptic activity regulates the amount of $A \beta$ secreted into $\mathrm{CSF}^{32,33}$ in mice. In humans, $A \beta$ is also rapidly secreted and cleared from the CSF, presumably governed by similar mechanisms ${ }^{34}$.

The next major insight came from families with autosomal dominant Alzheimer's disease (Familial AD- FAD) that occurred well before the age of 65 . In some of these families, Alzheimer's

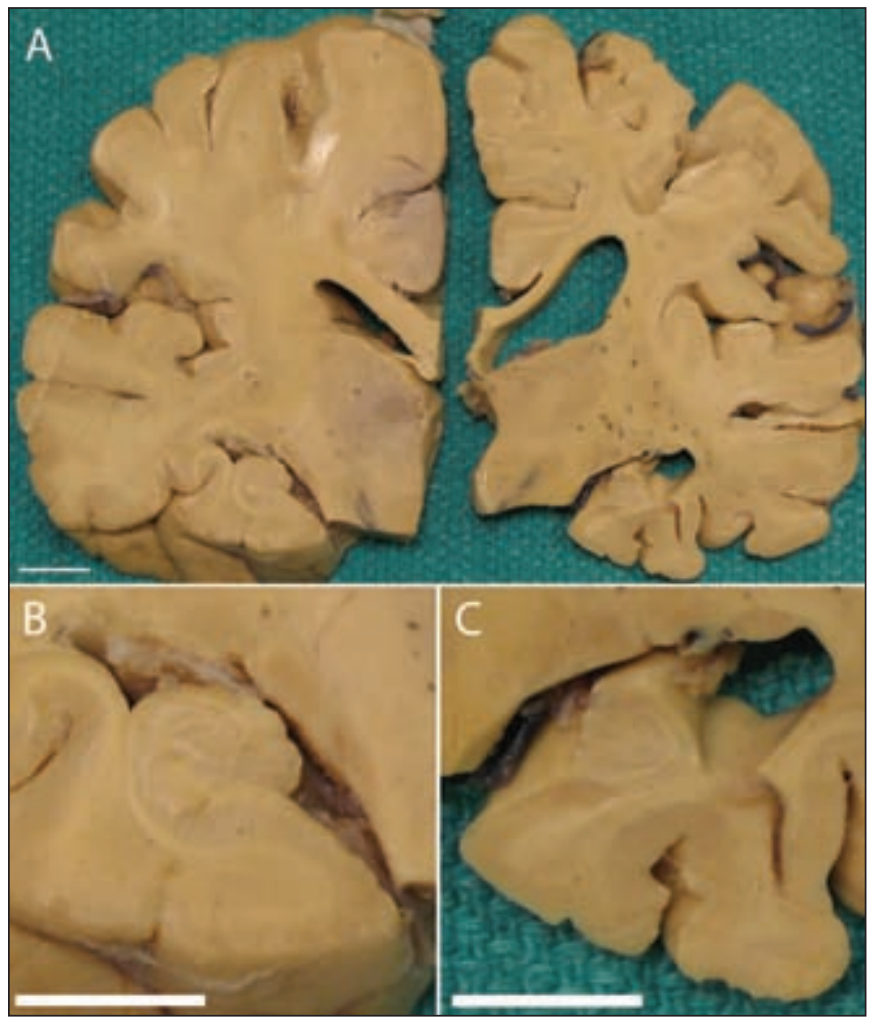

Figure 2: Alzheimer's disease gross pathology. Panel A shows comparable coronal sections of a normal brain on the (left) compared with the brain with a neuropathological diagnosis of $A D$ (right). Inset are close up images of the hippocampus showing a normal brain $(B)$ and demonstrating the marked atrophy/tissue loss in Alzheimer's disease $(C)$. Scale bar $1 \mathrm{~cm}$. 


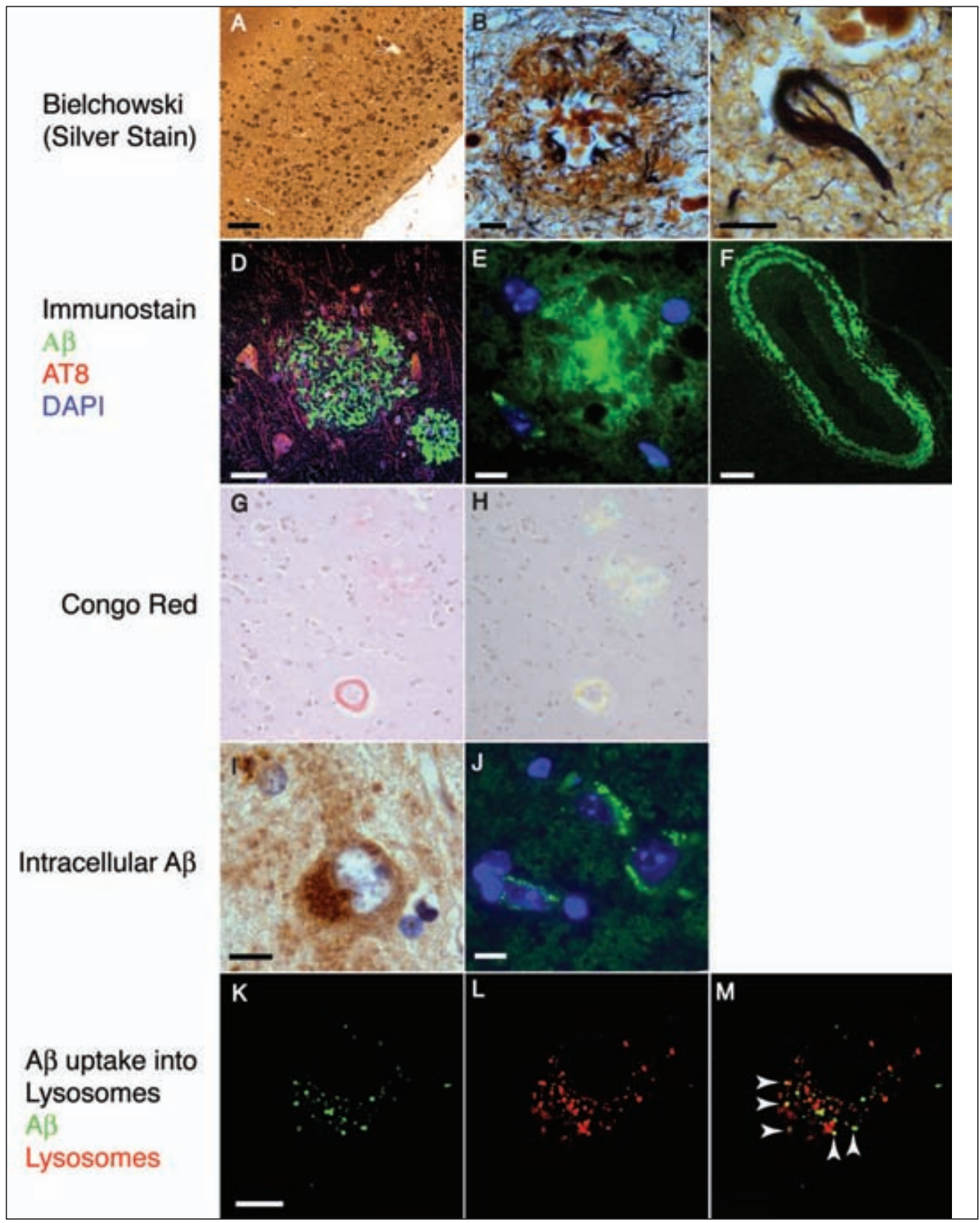

Figure 3: Extracellular and Intracellular Pathology in Alzheimer's disease. A-C) Human brain from an AD patient stained with Modified Bielschowsky silver stain. A low power view of human temporal cortex (A) (scale bar $200 \mu \mathrm{m}$ ). High power views of the same case, showing an amyloid plaque $(B)$ with amyloid appearing brown and dystrophic neuritis and tangles appearing black (Scale bar $=10 \mu \mathrm{m})$ and $(C)$ a neurofibrillary tangle $($ Scale bar $=10 \mu \mathrm{m}) . D-F)$ Immunohistochemistry with formic acid pretreatment (antigen retrieval) shows an (D) amyloid plaque stained with antibodies to AR42 (green) and an antibody to AT8 (abnormally phosphorylated tau) in red. Nuclei are in blue. (Scale Bar $=30 \mu \mathrm{m})$. (E) An amyloid plaque immunostained with an antibody against $A \beta 42$ (green) in the brain of a transgenic APP-Swe PS1- $\triangle$ exon 9 mouse (Scale bar $10 \mu \mathrm{m})$. F) Vascular amyloid in a human stained with an antibody to A $\beta 42$ (green). (Scale bar $150 \mu \mathrm{m})$. G-H Classical Congo red stain of vascular and plaque amyloid showing red staining under while light $G(G)$, but apple-green birefringence under polarized light $(H ; 400 X)$. I-J Intracellular amyloid is seen using heat treatment (Retriever 2100) to immunostain intracellular granules of A $\beta 42$ inclusions in humans (I, brown) (Scale

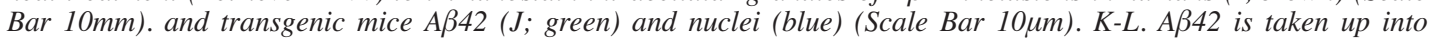
lysosomes. Neuronal SN56 cells allowed to take up 250nM HiLyte Fluor 488 labeled A 342 for 24 hours. A 342 is green $(K)$ and lysosomes were marked by transfected LAMP1 tagged with $\mathrm{mRFP}(\mathrm{L} ; \mathrm{red})$. Merged image $(M)$ shows colocalized pixels in yellow marked with arrows (Scale Bar $10 \mu \mathrm{m}$ ) 
disease mapped to the APP gene. To date, 32 mutations (in 86 families) in APP have been described (http://www.molgen. ua.ac.be/ADMutations). These mutations generally fall into three classes. One type of mutation, the Swedish mutation, is located adjacent to the $\beta$-cleavage site of APP where it increases the rate of $\beta$-cleavage up to 10 -fold, resulting in increased production of all amyloid species ${ }^{35}$. Another group of mutations near the $\gamma$-site of APP alters the specificity of the $\gamma$-secretase cleavage by increasing the relative amount of the more toxic A $\beta 42$ produced (e.g. the London mutation) $)^{36-38}$. In addition, point mutations within the $A \beta$ sequence itself that appear to decrease $\alpha$-cleavage, increase the stability of $A \beta$ or increase its propensity to aggregate (e.g. the Arctic, Dutch and the Iowa mutations ${ }^{39-41}$ ). FAD can also occur due to increased APP expression due to promoter mutations ${ }^{42}$ or by the simple gene duplication of APP ${ }^{43-45}$. Thus, from the point of view of genetic defects on chromosome 21, anything that increases the amount of $\mathrm{A} \beta$ or $\mathrm{A} \beta 42$ is tightly associated with AD.

\section{Not just chromosome 21}

Even early on, it was apparent that many FAD families mapped outside chromosome 21. A FAD-linked locus was mapped to chromosome 14 by Peter St. George Hyslop's group at the University of Toronto ${ }^{46}$. This led to the identification of mutations in the protein presenilin-1 (PS1) and a second homologous gene on chromosome 1 dubbed PS2 $2^{47,48}$. These patients often have additional features such as seizures, myoclonus, long tract signs, ataxia and psychiatric symptoms ${ }^{49}$. With much subsequent work, presenilin was found to be the catalytic protein in a large enzyme complex called the $\gamma$ secretase, which is composed of at least 4 proteins (presenilin, nicastrin, mAph1 and PEN2 ${ }^{50-55}$ ) Recombinant PS1 is able to catalyze $\gamma$-secretase cleavage on its $\mathrm{own}^{56}$, and mutations at either of two critical aspartate residues in PS-1 and PS-2 within the catalytic site abolishes its enzymatic activity ${ }^{57}$. PS also contains the binding site of pharmacological $\gamma$-secretase inhibitors $^{58,59}$. Currently, mutations in PS1 account for the largest identified group of FAD, with 177 mutations described in PS1 (392 families) and 14 mutations described in PS2 (23 families) (http://www.molgen.ua.ac.be/ADMutations) ${ }^{60}$.

While the exact mechanism(s) by which FAD PS mutations alter $\gamma$-secretase function remain to be elucidated, they are believed to cause $\mathrm{AD}$ by increasing the relative amount of $\mathrm{A} \beta 42$ to $A \beta 40^{56,61,62}$, even when they reduce the total amount of $A \beta$ produced $^{63}$. The average age of onset in human families correlates with the $A \beta 42 / 40$ ratio $^{64}$. It is interesting to note that the identification of PS was based solely on genetics with no preconceived notion of their biochemical functions.

\section{Late Onset AD}

The genetics of Late Onset Alzheimer's disease has proven more difficult. To date, the best-characterized locus is the Apoliporotein (ApoE) gene. In humans, ApoE has three alleles namely e2, e3, and e4 which differ by only a few amino acids. Individuals with 1 e4 allele are at a 2-3 fold increased risk for Alzheimer's disease and having 2 e 4 increases the risk about 12 fold $^{65}$. Some studies suggest that the ApoE2 allele is protective against $\mathrm{AD}^{66}$. The mode of action of ApoE also supports the importance of amyloid, as the e4 allele appears to increase the rate of $\mathrm{A} \beta$ fibril formation in-vitro ${ }^{67,68}$ and to increase the observed amount of $A \beta$ deposition in mice and humans ${ }^{69,70}$. More recent evidence suggests that ApoE isoform also controls $\mathrm{A} \beta$ clearance from the CSF of transgenic mice ${ }^{71}$.

It is estimated that $60-80 \%$ of Alzheimer's disease risk may be heritable ${ }^{72}$ and many groups are searching for the missing genetic risk factors. In the last few years, new micro-array based techniques of screening referred to as Genome Wide Association Studies (GWAS) have substantially increased the number of candidate genes ${ }^{73-76}$. The AlzGene database (http://www. alzgene.org/TopResults.asp) currently lists the top ten genes likely to be risk factors for $\mathrm{AD}$. Unfortunately these putative genes (assuming that they prove to be correct) each accounts for only very small risk of $\mathrm{AD}$ (Odds Ratio of $\sim 1.25$ ) meaning that they are much less powerful than ApoE ${ }^{73-77}$.

\section{Challenges To The Original Amyloid Hypothesis?}

Despite the importance of $A \beta$, there were a number of important drawbacks to the original Amyloid Hypothesis. The most serious of these were that amyloid plaque load does not correlate well with cognitive function or disease progression in humans ${ }^{78,79}$ or mice ${ }^{80}$. In fact, neurofibrillary tangles (NFT's) correlated better with cognitive impairment, leading many to suspect they might be the critical causative agent in $\mathrm{AD}^{78,79}$.

\section{Tangles: the fall and the return}

Neurofibrillary tangles (NFTs) are made up of intracellular aggregates of paired helical filaments of the protein tau, which have become hyperphosphorylated ${ }^{78,79}$ (Figure 3). Although NFT's correlate well with AD onset and progression ${ }^{81}$, to date, no tau mutations have been found in AD families. Instead, tau mutations cause phenotypically distinct diseases including frontotemporal dementia, which do not display plaques, suggesting that tau pathology in $\mathrm{AD}$ is downstream of $\mathrm{A} \beta^{79,82}$. This idea also is supported by pathological studies in Down syndrome and transgenic mice that demonstrate that amyloid plaques precede the appearance of NFT's ${ }^{83,84}$. Furthermore, treatments that increase $A \beta$ oligomers in mouse models lead to increased tau pathology $85-88$. Conversely, immunotherapy to deplete $\mathrm{A} \beta$ clears amyloid plaques and reduces early tau aggregates, although later stage tau aggregates are not reversible ${ }^{87}$. Other experiments suggest that tau does have a role in $\mathrm{AD}$ as reducing tau levels or disrupting tau's interactions with signaling proteins reduces pathology and improves memory ${ }^{89-91}$. Therefore, tau is likely still important in AD, but its effects are downstream from $A \beta$.

\section{Amyloid: Are Plaques a distraction?}

Although amyloid plaques might be the most striking aspect of AD pathology (Figure 3), the best pathological correlate of cognitive impairment is loss of synapses ${ }^{92-95}$. Synaptic loss correlates not with insoluble amyloid fibrils in plaques but with levels of soluble amyloid species in the brain ${ }^{96.97}$. A $\beta$ are now recognized to aggregate into a wide variety of soluble structures, from simple dimers and trimers to large soluble oligomers sometimes referred to as Amyloid Derived Diffusible Ligands (ADDLs) and A $\beta 56^{* 95,98-100}$. These soluble aggregates are orders of magnitude more toxic to neurons and synapses than the 
insoluble amyloid fibrils in plaques ${ }^{20.21}$. In animal models, soluble $A \beta$ impairs learning performance and decreases the number of synapses ${ }^{100-102}$. These changes are reversible through clearing or antibody chelation of $\mathrm{A} \beta^{103-105}$. Furthermore, oligomeric $\mathrm{A} \beta$ binds directly to synapes containing glutamate neurotransmitter receptors (including N-methyl D-Aspartic Acid (NMDA) receptors) causing a rapid decrease in receptors, reducing signaling, disrupting the structure of the synapse $^{99,103,106,107}$ and depleting synaptic vesicles ${ }^{108}$. A $\beta$ oligomers have also been proposed to impair LTP by binding to the prion protein $(\mathrm{PrP})^{109-111}$ although this is currently controversial $^{105,112}$. It is these small soluble amyloid oligomers that are now the main focus of the Amyloid Hypothesis.

\section{Intracellular Amyloid. The Other Half?}

While the discovery of soluble amyloid aggregates may explain the acute effects of amyloid toxicity, it might not explain more chronic changes of $\mathrm{AD}$ including alterations of neuronal structure, neuronal loss, or the origin of plaques. One possible inroad to understanding these changes comes from the study of A $\beta$ aggregation inside living cells.

The endosomal/ lysosomal system comprises a series of intracellular compartments that are responsible for taking up extracellular material and proteins from the cell surface. Internalized material is transported to early endosomes, where they are sorted, and then either recycled to the cell surface or transported to late endosomes/ multivesicular bodies and then to lysosomes (See Figure 4). A parallel system called macroautophagy (referred to hereafter as autophagy) provides a parallel pathway for the degradation of long-lived intracellular proteins and organelles such as mitochondria. Autophagy begins with double-layered sheets of membrane arising from the endoplasmic reticulum engulfing regions of cytoplasm to form double walled autophagic vesicles. These vesicles may then fuse with endosomes to acquire hydrolytic (digestive) enzymes, and eventually fuse with lysosomes ${ }^{113,114}$.

Lysosomes are highly acidic ( $\mathrm{pH}$ 4.5) compartments containing $>80$ hydrolytic (digestive) enzymes. ${ }^{115-118}$. Lysosomes are recognized clinically because of more than 40 Lysosomal Storage Diseases (LSDs), which are usually caused by the absence of a critical catabolic (digestive) enzyme resulting in a buildup of undigested material in lysosomes. When they involve the central nervous system, these diseases lead to dementia and death ${ }^{119}$. Although lysosomes are traditionally thought of as simply a waste disposal/digestive system, they are now also recognized as a secretory compartment in a wide variety of cell types including thyroid hormone, pulmonary surfactant, albumin, cytotoxic compounds from lymphocytes and neurtrophils ${ }^{120-122}$. Lysosomes are also able to fuse with the cell membrane in order to repair damage to the cell surface ${ }^{123}$.

The endosomal/ lysosomal system plays a role in $\mathrm{A} \beta$ production. This was best demonstrated in experiments in which APP is labeled on the cell surface and followed as it is internalized, cleaved into $A \beta$, and then secreted or retained intracellularly ${ }^{124-128}$. Moreover, increasing the rate of internalization of APP increases A $\beta$ generation, and blocking internalization reduces $A \beta$ levels ${ }^{32,125,129-137}$. Autophagosomes have also been demonstrated to contain APP, $\beta$ - and $\gamma$-secretases and to produce $A \beta^{138,139}$. Our own work has demonstrated that
APP and $\gamma$-secretase activity are highly enriched in lysosomes $^{140,141}$. We have also found that APP undergoes unexpectedly rapid direct transport to the lysosome from the cell surface $^{142}$ and from internal compartments and these pathways may play a role in $\mathrm{A} \beta$ production (unpublished observations) ${ }^{143}$.

Although the spontaneous intracellular accumulation of A $\beta 42$ has long been recognized in cultured neuronal cells ${ }^{144-148}$, the histological detection of intracellular $A \beta$ in tissue has only been recognized relatively recently. This is likely because the standard techniques used to immunostain amyloid plaques rely on concentrated formic acid; formic acid improves appearance of plaques, but can wash away intracellular deposits ${ }^{149-151}$. Reliable detection of intracellular $A \beta$ therefore requires optimizal tissue preparation techniques (antigen retrieval) along with careful selection of highly specific, high affinity antibodies ${ }^{152}$ (reviewed $\left.i^{153}\right)$. Although it still has detractors ${ }^{154}$, the concept of intracellular $A \beta$ accumulation is now widely accepted ${ }^{153,155-157}$. Figure 3 shows examples of extracellular and intracellular $A \beta$.

Intracellular accumulation of $\mathrm{A} \beta 42$ in the endosomal/ lysosomal system has been observed in transgenic Alzheimer's disease mice either before or accompanying cognitive impairment, but well before the appearance of amyloid plaques ${ }^{158-166}$. Intracellular $\mathrm{A} \beta 42$ has been shown in human

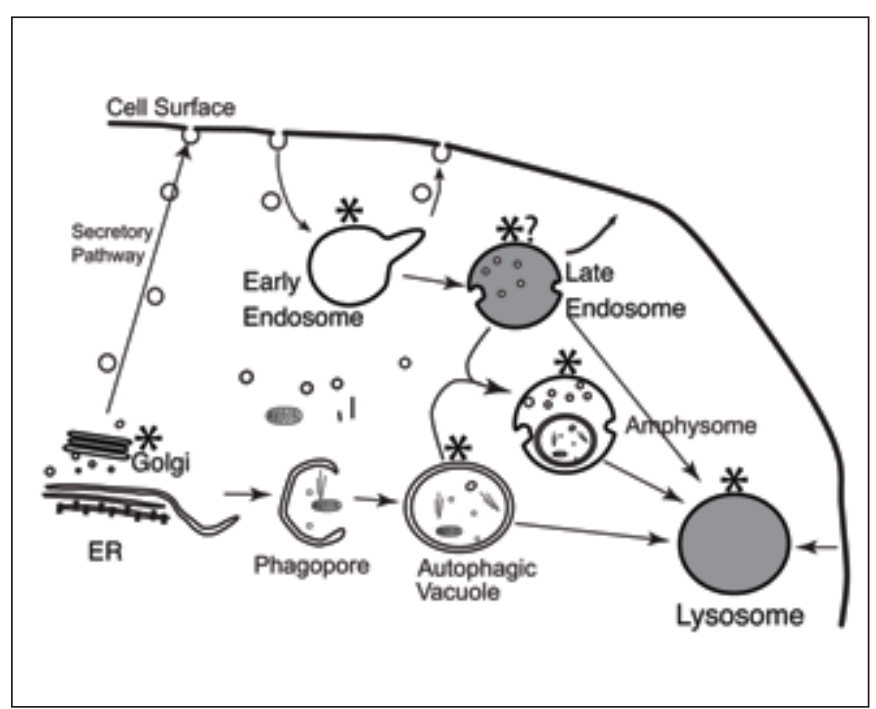

Figure 4: Overview of the endosomal/lysosomal and autophagy systems. Proteins are synthesized in the ER and transit to the Golgi, where they are glycosylated and exported. Cell surface proteins, transmembrane proteins, and extracellular material are endocytosed to early endosomes (EE). From there they may recycle to the cell surface or transit to the late endosome (LE) and to the lysosome. APP can also be transported directly from the cell surface to the lysosome. Macroautophagy begins with membrane extending out of the ER, which becomes a Phagopore that engulfs cytoplasm and organelles into double membrane bound Autophagic Vacuoles. Autophagic Vacuoles can fuse with endosomes to form Amphysomes or directly with lysosomes. Lysosomes that contain residual indigestible autofluorescent material remain as lipofuscin granules. Compartments implicated in A $\beta$ production are marked $*$ (it is not known if $A \beta$ is made in the late endosome and this compartment is labeled *?). Compartments implicated in $A \beta$ accumulation are shaded. 
neuropathological material in both Alzheimer's disease and Down's Syndrome patients, where it also appears to fill neuronal lysosomal compartments before the appearance of plaques $^{44,149,151,167-170}$. Recent studies using Laser Capture Microdissection to collect groups of neurons from AD brains and directly assay their $\mathrm{A} \beta$ content have confirmed that the histological appearance of increased $A \beta$ in fact reflects true intracellular amyloid accumulation in human brain ${ }^{171,172}$.

The intracellular accumulation of $A \beta$ may play a role in $A D$ pathology. This is because $A \beta$ fibrils found in plaques are preferentially nucleated by both lysosomal gangliosides (complex lipids and carbohydrates) and the lysosomal $\mathrm{pH}$ of 4.5 173-177. Furthermore, in-vitro experiments demonstrate that $\mathrm{A} \beta$ fibril formation directly disrupts lipid membranes ${ }^{175,178}$. These effects come together in experiments that show $\mathrm{A} \beta$ taken up from the media can nucleate further $A \beta$ aggregation ${ }^{155,179-182}$. From there, it can directly disrupt the structures of neurons and synapses $^{183}$ or cause lysosomal rupture leading to cell death $^{184,185}$. Cell death is likely due to the release of digestive enzymes into the cytoplasm, or their secondary activation of programmed cell death pathways ${ }^{143,186}$.

The propensity for $\mathrm{A} \beta$ to aggregate in the acidic environment of the lysosome suggests that extracellular amyloid plaques may begin as amyloid 'seeds' in the lysosome. This idea is supported by evidence that cell death begins only after intracellular $A \beta 42$ is detected ${ }^{187}$ and that the amount of intracellular $A \beta 42$ decrease as plaques appear ${ }^{164,188}$. In addition, the presence of many active lysosomal enzymes in plaques suggests that lysosomal contents directly contributed to plaques ${ }^{189-192}$. Furthermore, remnants of neuronal cell bodies are often seen in the center of mature 'dense core' plaques suggesting that these cells were lysed to form the beginnings of the plaque ${ }^{167,193}$. Recent experiments using confocal microscopy in live mouse brains have demonstrated that plaques can appear rapidly over 24 hours ${ }^{194}$, confirming that plaques can appear acutely.

\section{A different route to pathology in AD?}

Abnormalities in the endosomal/lysosomal system have been recognized in Alzheimer's disease pathological material since the early 1990's. Even before the onset of clinical disease, there is a marked increase in the number and size of lysosomes in brain regions most vulnerable to Alzheimer's disease. As Alzheimer's disease advances, lysosomes multiply and appear to fill neurons ${ }^{115,191,195-197}$. Using electron microscopy, it is now recognized that many of these compartments are autophagic vacuoles that are also undergoing massive upregulation ${ }^{138,198}$. In fact, the dystrophic neurites characteristic of AD are actually neuronal processes filled predominantly with autophagic vacuoles $^{199}$. Autophagy in neurons is highly efficient and autophagosomes are not normally observed, and their appearance suggests a pathological failure of this system ${ }^{200}$.

The accumulation of lysosomes and autophagosomes in AD is strikingly similar to the pathology seen in Lysosomal Storage Diseases (LSDs) ${ }^{199}$. These diseases are also accompanied by a prominent failure of autophagy ${ }^{119,199}$, and the failure of autophagy can cause neurodegeneration on its $\mathrm{own}^{201}$ and may represent a mode of cell death ${ }^{119}$. Conversely, the failure of the lysosomal system in a number of LSD's can also lead to elevated levels of $A \beta$ and tau; these include Niemann-Pick Type $C^{202}$, Tay
Sach's and Sandhoff's disease ${ }^{203}$ and mucopolysaccharidosis ${ }^{204}$. These effects can be partly replicated experimentally; inhibiting lysosomal proteolysis causes buildup of autophagic vacuoles in processes very similar to $\mathrm{AD}^{205}$, and overloading cells with gangliosides inhibits APP degradation and increases A $\beta$ production $^{203,206}$.

Recently, PSs have emerged as a potentially unifying factor in these pathologies. PS1 is important for clearance of proteins from endosomes ${ }^{207}$, for clearance of proteins by autophagy 199,208,209 and for trafficking through the endosomal lysosomal system ${ }^{210}$. In a recent twist, PS mutations have been shown to directly impair lysosomal function by preventing lysosomal acidification ${ }^{211}$ suggesting that FAD might be in effect a Lysosomal Storage Disease. Thus, PS mutations can lead to cell death by two different pathophysiological processes. On the one hand they are responsible for producing toxic $A \beta$ species, and on the other hand they block autophagy, impairing the cell's ability to clear $\mathrm{A} \beta$ (and perhaps tau).

Defects in autophagy and intracellular $A \beta$ clearance may represent a therapeutic target. This was shown dramatically in recent experiments in which knocking-out an endogenous lysosomal protease inhibitor (cystatin B) increases the clearance of intracellular $A \beta$, reduces the number of autophagic vesicles, decreases plaques, and prevents the development of cognitive changes $^{212}$. A number of 'lysosomal modulatory' drugs are under study, that increase the levels of lysosomal enzymes and appear to reduce Alzheimer's pathology in a tissue slice model of $\mathrm{AD}^{213,214}$.

Taken together, these data suggest that in addition to the acute extracellular effects of $A \beta$ oligomers, $A \beta$ also accumulates intracellularly as either a cause or a consequence of lysosomal dysfunction, which results in neurons exhibiting neuropathological changes reminiscent of classic LSD. These intracellular changes can cause pathology independently from the acute synaptotoxic effects of extracellular $A \beta$ oligomers. Amyloid plaque formation might be secondary to neuronal lysis and release of intracellular $A \beta$.

\section{Conclusions: Where To From Here?}

Although the Amyloid Hypothesis has gone through a number of twists and turns, amyloid still appears to be an important causal factor in AD. However, the true proof of this model will ultimately rest on whether amyloid-reducing therapies can treat Alzheimer's disease. A large number of compounds are currently in clinical trials. Generally antiamyloid treatments fall into several classes, including compounds that inhibit $A \beta$ production (by inhibiting secretase enzymes) and compounds which bind $A \beta$ to impair aggregation, neutralize toxicity or increase clearance ${ }^{215,216}$. These include antibody-based strategies of active immunization and passive immunization with monoclonal or polyclonal antibodies ${ }^{87,217-222}$, or small molecules such as Scyloinositol ${ }^{223}$. Although these strategies are effective in treating mice, there have been a number of high profile failures in clinical trials, including Tarenflurbil and LY451039 (secretase modulators/ inhibitors) and Alzmed (tramiprosate; an aggregation inhibitor) ${ }^{224}$. In addition, we know from a discontinued $A \beta$ vaccination trial in humans, that clearance of $A \beta$ plaques alone is not sufficient to improve symptoms 225,226 . 
Some have taken these failures to mean that there is a problem with the Amyloid hypothesis itself. Before coming to that conclusion, we must first look at the limitations of these trials. Currently, AD is a clinical diagnosis, made only after the appearance of cognitive impairment. However, AD has a long presyptomatic phase suggested to be years to decades 227,228 , during which neuropathological changes and subtle cognitive and imaging changes can be observed ${ }^{229-232}$. While the transition from presymptomatic disease to $\mathrm{AD}$ is difficult to identify clinically, it is important to be able to do so, because neuronal loss begins at the earliest clinical changes of AD (transition from a Clinical Dementia Rating scale score (CDR) of 0 (asymptomatic) to a CDR of 0.5 (very mild dementia) ${ }^{233,234}$. Numerous biomarkers are under study to try to detect or predict this transition to AD. These include CSF protein levels (tau and $\mathrm{A} \beta$ ), volumetric MRI to quantitate atrophy, and nuclear medicine-based scans of brain glucose uptake and amyloid load (e.g. Pittsburgh compound or PiB scans). Although these are promising, they are still considered research tools ${ }^{227,235-238}$.

From animal studies, we know that even modest reductions in $\mathrm{A} \beta$ production can dramatically reduce amyloid deposits and improve memory ${ }^{165,223}$, but only early pathology may be reversible ${ }^{87}$. In humans, a number of other factors will likely complicate clinical applications. For example, amyloid found in human brains is much more insoluble than amyloid produced in mice, ${ }^{239}$ suggesting that it will be more difficult to clear. In addition, the $\gamma$-secretase also processes a large number of other important regulatory proteins (most notably the Notch receptor) and inactivation is toxic in many tissues and lethal to embryos ${ }^{240-}$ ${ }^{242}$. A safe $\gamma$-secretase inhibitor will need to selectively block $A \beta$ production without impairing its other functions. It must also be pointed out that the failed trials were first generation agents which had significant technical limitations and were advanced to phase 3 trials without being successful in phase 2 trials ${ }^{224}$.

More concerning, however, is that transgenic mice used to develop these treatments generally do not exhibit the high levels of neuronal loss seen in $\mathrm{AD}$. In fact, it has been argued that transgenic mice only model early $\mathrm{AD}$, while the trials were looking at established $\mathrm{AD}^{224}$. This fundamental mismatch between the mouse models and the human patients might therefore be the largest obstacle for the therapeutic application of the Amyloid Hypothesis.

It may be that that anti-amyloid agents will only be effective if they are used before irreversible damage has occurred, or in other words before symptoms appear. Therapeutic trials may not work without better diagnostics to allow identification of patients with presymptomatic or very early $\mathrm{AD},{ }^{224}$. With the oncoming tidal wave of patients, the cost of failure to treat or cure Alzheimer's disease will be staggering. If we are to affect the course of $\mathrm{AD}$, safer and more effective amyloid lowering treatments will need to be coupled with better, earlier, presymptomatic diagnosis.

\section{ACKNOWLEDGEMENTS}

This work is supported by CIHR grant MOP-82890 to S.H.P. One of the authors (S.H.P.) has received some research funding as a result of patients in clinical trials mentioned in the article (Elan, Eli Lilly, Jansen Ortho, Myriad Genetics). The authors thank the Molecular Pathology Laboratory at the Robarts
Research Institute for performing hystology, Drs. Vania Prado and Marco Prado for providing the APPSwe/PS1 9 mouse model of AD and Marco Prado for constructice feedback on the manucript.

\section{REFERENCES}

1. Hebert LE, Scherr PA, Beckett LA, et al. Age-specific incidence of Alzheimer's disease in a community population. JAMA. 1995; 273(17):1354-9.

2. Jorm AF. Cross-national comparisons of the occurrence of Alzheimer's and vascular dementias. Eur Arch Psychiatry Clin Neurosci. 1991;240(4-5):218-22.

3. Smetanin P, Lobak P, Stiff D, Sherman G, Ahmad S. Rising tide: the impact of demetia in Canada 2008-2038. Report by RiskAnalytica; 2009 [Cited Nov 8 2011; Available from: http://www.alzheimer.ca/english/rising_tide/rising_tide_report.h tm].

4. Hebert LE, Scherr PA, Bienias JL, Bennett DA, Evans DA. Alzheimer disease in the US population: prevalence estimates using the 2000 census. Arch Neurol. 2003 Aug;60(8):1119-22.

5. Mebane-Sims I, Association As. 2009 Alzheimer's disease facts and figures. Alzheimers Dement. 2009 May;5(3):234-70.

6. International AsD. 2009. World Alzheimer Report 2009 [cited Nov 8 2011; Available from: http://www.alz.org/national/documents/ report_full_2009worldalzheimerreport.pdf].

7. Nelson PT, Braak H, Markesbery WR. Neuropathology and cognitive impairment in Alzheimer disease: a complex but coherent relationship. J Neuropathol Exp Neurol. 2009 Jan;68 (1):1-14.

8. Selkoe DJ. Toward a comprehensive theory for Alzheimer's disease. Hypothesis: Alzheimer's disease is caused by the cerebral accumulation and cytotoxicity of amyloid beta-protein. Ann NY Acad Sci. 2000;924:17-25.

9. Golde TE. The Abeta hypothesis: leading us to rationally-designed therapeutic strategies for the treatment or prevention of Alzheimer disease. Brain Pathol. 2005 Jan;15(1):84-7.

10. Hussain I, Powell D, Howlett DR, et al. Identification of a novel aspartic protease (Asp 2) as beta-secretase. Mol Cell Neurosci. 1999; 14(6):419-27.

11. Vassar R, Bennett BD, Babu-Khan S, et al. Beta-secretase cleavage of Alzheimer's amyloid precursor protein by the transmembrane aspartic protease BACE. Science. 1999;286(5440):735-41.

12. Yan R, Bienkowski MJ, Shuck ME, et al. Membrane-anchored aspartyl protease with Alzheimer's disease beta- secretase activity. Nature. 1999;402(6761):533-7.

13. Sinha S, Anderson JP, Barbour R, et al. Purification and cloning of amyloid precursor protein beta-secretase from human brain. Nature. 1999;402(6761):537-40.

14. Lin X, Koelsch G, Wu S, Downs D, Dashti A, Tang J. Human aspartic protease memapsin 2 cleaves the beta-secretase site of beta-amyloid precursor protein. Proc Natl Acad Sci USA. 2000 Feb 15;97(4):1456-60.

15. Kao SC, Krichevsky AM, Kosik KS, Tsai LH. BACE1 suppression by RNA interference in primary cortical neurons. J Biol Chem. 2004 Jan 16;279(3):1942-9.

16. Allinson TM, Parkin ET, Turner AJ, Hooper NM. ADAMs family members as amyloid precursor protein alpha-secretases. J Neurosci Res. 2003 Nov 1;74(3):342-52.

17. Koike H, Tomioka S, Sorimachi $\mathrm{H}$, et al. Membrane-anchored metalloprotease MDC9 has an alpha-secretase activity responsible for processing the amyloid precursor protein. Biochem J. 1999;343 Pt 2:371-5.

18. Lammich S, Kojro E, Postina R, et al. Constitutive and regulated alpha-secretase cleavage of Alzheimer's amyloid precursor protein by a disintegrin metalloprotease. Proc Natl Acad Sci USA. 1999;96(7):3922-7.

19. Sinha S, Lieberburg I. Cellular mechanisms of beta-amyloid production and secretion. Proc Natl Acad Sci USA. 1999 Sep 28; 96(20):11049-53.

20. Kayed R, Head E, Thompson JL, et al. Common structure of soluble amyloid oligomers implies common mechanism of pathogenesis. Science. 2003 Apr 18;300(5618):486-9. 
21. Glabe CG. Structural classification of toxic amyloid oligomers. J Biol Chem. 2008 Oct 31;283(44):29639-43.

22. Querfurth HW, LaFerla FM. Alzheimer's disease. N Engl J Med. 2010 Jan 28;362(4):329-44.

23. Ellis WG, McCulloch JR, Corley CL. Presenile dementia in Down's syndrome. Ultrastructural identity with Alzheimer's disease. Neurology. 1974 Feb;24(2):101-6.

24. Wisniewski KE, Wisniewski HM, Wen GY. Occurrence of neuropathological changes and dementia of Alzheimer's disease in Down's syndrome. Ann Neurol. 1985 Mar;17(3):278-82.

25. Glenner GG, Wong CW. Alzheimer's disease and Down's syndrome: sharing of a unique cerebrovascular amyloid fibril protein. Biochem Biophys Res Commun. 1984 Aug 16;122(3): $1131-5$

26. Masters CL, Simms G, Weinman NA, Multhaup G, McDonald BL, Beyreuther K. Amyloid plaque core protein in Alzheimer disease and Down syndrome. Proc Natl Acad Sci USA. 1985 Jun;82(12): 4245-9.

27. Tanzi RE, Gusella JF, Watkins PC, et al. Amyloid beta protein gene: cDNA, mRNA distribution, and genetic linkage near the Alzheimer locus. Science. 1987 Feb 20;235(4791):880-4.

28. Kang J, Lemaire HG, Unterbeck A, et al. The precursor of Alzheimer's disease amyloid A4 protein resembles a cell-surface receptor. Nature. 1987 Feb 19-25;325(6106):733-6.

29. Haass C, Schlossmacher MG, Hung AY, et al. Amyloid beta-peptide is produced by cultured cells during normal metabolism. Nature. 1992 Sep 24;359(6393):322-5

30. Seubert P, Vigo-Pelfrey C, Esch F, et al. Isolation and quantification of soluble Alzheimer's beta-peptide from biological fluids. Nature. 1992 Sep 24;359(6393):325-7.

31. Shoji M, Golde TE, Ghiso J, et al. Production of the Alzheimer amyloid beta protein by normal proteolytic processing. Science. 1992;258(5079):126-9.

32. Cirrito JR, Kang JE, Lee J, et al. Endocytosis is required for synaptic activity-dependent release of amyloid-beta in vivo. Neuron. 2008 Apr 10;58(1):42-51.

33. Cirrito JR, Yamada KA, Finn MB, et al. Synaptic activity regulates interstitial fluid amyloid-beta levels in vivo. Neuron. 2005 Dec 22;48(6):913-22.

34. Bateman RJ, Munsell LY, Morris JC, Swarm R, Yarasheski KE, Holtzman DM. Human amyloid-beta synthesis and clearance rates as measured in cerebrospinal fluid in vivo. Nat Med. 2006 Jul;12(7):856-61.

35. Mullan M, Crawford F, Axelman K, et al. A pathogenic mutation for probable Alzheimer's disease in the APP gene at the N-terminus of beta-amyloid. Nat Genet. 1992 Aug;1(5):345-7.

36. Goate A, Chartier-Harlin MC, Mullan M, et al. Segregation of a missense mutation in the amyloid precursor protein gene with familial Alzheimer's disease. Nature. 1991 Feb 21;349(6311): 704-6.

37. Eckman CB, Mehta ND, Crook R, et al. A new pathogenic mutation in the APP gene $(\mathrm{I} 716 \mathrm{~V})$ increases the relative proportion of A beta 42(43). Hum Mol Genet. 1997 Nov;6(12):2087-9.

38. Hendriks L, van Duijn CM, Cras P, et al. Presenile dementia and cerebral haemorrhage linked to a mutation at codon 692 of the beta-amyloid precursor protein gene. Nat Genet. 1992 Jun;1(3): 218-21.

39. Cheng IH, Palop JJ, Esposito LA, Bien-Ly N, Yan F, Mucke L. Aggressive amyloidosis in mice expressing human amyloid peptides with the Arctic mutation. Nat Med. 2004 Nov;10(11): $1190-2$

40. Nilsberth C, Westlind-Danielsson A, Eckman CB, et al. The 'Arctic' APP mutation (E693G) causes Alzheimer's disease by enhanced Abeta protofibril formation. Nat Neurosci. 2001 Sep;4(9): 887-93.

41. Van Nostrand WE, Melchor JP, Cho HS, Greenberg SM, Rebeck GW. Pathogenic effects of D23N Iowa mutant amyloid beta protein. J Biol Chem. 2001 Aug 31;276(35):32860-6.

42. Theuns J, Brouwers N, Engelborghs S, et al. Promoter mutations that increase amyloid precursor-protein expression are associated with Alzheimer disease. Am J Hum Genet. 2006 Jun; 78(6):936-46.
43. Rovelet-Lecrux A, Hannequin D, Raux G, et al. APP locus duplication causes autosomal dominant early-onset Alzheimer disease with cerebral amyloid angiopathy. Nat Genet. 2006 Jan; 38(1):24-6

44. Cabrejo L, Guyant-Marechal L, Laquerriere A, et al. Phenotype associated with APP duplication in five families. Brain. 2006 Nov;129(Pt 11):2966-76.

45. Sleegers K, Brouwers N, Gijselinck I, et al. APP duplication is sufficient to cause early onset Alzheimer's dementia with cerebral amyloid angiopathy. Brain. 2006 Nov;129(Pt 11): 2977-83.

46. Sherrington R, Rogaev EI, Liang Y, et al. Cloning of a gene bearing missense mutations in early-onset familial Alzheimer's disease. Nature. 1995;375(6534):754-60.

47. Rogaev EI, Sherrington R, Rogaeva EA, et al. Familial Alzheimer's disease in kindreds with missense mutations in a gene on chromosome 1 related to the Alzheimer's disease type 3 gene. Nature. 1995;376(6543):775-8.

48. Levy-Lahad E, Wasco W, Poorkaj P, et al. Candidate gene for the chromosome 1 familial Alzheimer's disease locus. Science. 1995 Aug 18;269(5226):973-7.

49. Butler R, Beattie BL, Thong UP, et al. A novel PS1 gene mutation in a large Aboriginal kindred. Can J Neurol Sci. 2010 May;37 (3):359-64

50. Yu G, Nishimura $M$, Arawaka $S$, et al. Nicastrin modulates presenilin-mediated notch/glp-1 signal transduction and betaAPP processing. Nature. 2000;407(6800):48-54

51. Lee SF, Shah S, Li H, Yu C, Han W, Yu G. Mammalian APH-1 interacts with presenilin and nicastrin and is required for intramembrane proteolysis of amyloid-beta precursor protein and Notch. J Biol Chem. 2002 Nov 22;277(47):45013-19.

52. Francis R, McGrath G, Zhang J, et al. aph-1 and pen-2 are required for Notch pathway signaling, gamma-secretase cleavage of betaAPP, and presenilin protein accumulation. Dev Cell. 2002 Jul;3(1):85-97.

53. Steiner H, Winkler E, Edbauer D, et al. PEN-2 is an integral component of the gamma-secretase complex required for coordinated expression of presenilin and nicastrin. J Biol Chem. 2002 Oct 18;277(42):39062-5

54. Kimberly WT, LaVoie MJ, Ostaszewski BL, Ye W, Wolfe MS, Selkoe DJ. Gamma-secretase is a membrane protein complex comprised of presenilin, nicastrin, Aph-1, and Pen-2. Proc Natl Acad Sci USA. 2003 May 27;100(11):6382-7.

55. Edbauer D, Winkler E, Regula JT, Pesold B, Steiner H, Haass C. Reconstitution of gamma-secretase activity. Nat Cell Biol. 2003 May;5(5):486-8

56. Ahn K, Shelton CC, Tian Y, et al. Activation and intrinsic gammasecretase activity of presenilin 1. Proc Natl Acad Sci USA. 2010 Dec 14;107(50):21435-40.

57. Kimberly WT, Xia W, Rahmati T, Wolfe MS, Selkoe DJ. The transmembrane aspartates in presenilin 1 and 2 are obligatory for gamma-secretase activity and amyloid beta-protein generation. J Biol Chem. 2000;275(5):3173-8.

58. Evin G, Sharples RA, Weidemann A, et al. Aspartyl protease inhibitor pepstatin binds to the presenilins of Alzheimer's disease. Biochemistry. 2001 Jul 27:40(28):8359-68.

59. Seiffert D, Bradley JD, Rominger CM, et al. Presenilin-1 and -2 are molecular targets for gamma-secretase inhibitors. J Biol Chem. 2000;275(44):34086-91

60. Horaitis O, Talbot CC, Jr., Phommarinh M, Phillips KM, Cotton RG. A database of locus-specific databases. Nat Genet. 2007 Apr;39(4):425.

61. Wolfe MS. When loss is gain: reduced presenilin proteolytic function leads to increased Abeta42/Abeta40. Talking Point on the role of presenilin mutations in Alzheimer disease. EMBO Rep. 2007 Feb;8(2):136-40.

62. Murayama O, Tomita T, Nihonmatsu N, et al. Enhancement of amyloid beta 42 secretion by 28 different presenilin 1 mutations of familial Alzheimer's disease. Neurosci Lett. 1999 Apr 9;265 (1):61-3.

63. Shimojo M, Sahara N, Murayama M, Ichinose H, Takashima A. Decreased Abeta secretion by cells expressing familial 
Alzheimer's disease-linked mutant presenilin 1. Neurosci Res. 2007 Mar;57(3):446-53.

64. Duering M, Grimm MO, Grimm HS, Schroder J, Hartmann T. Mean age of onset in familial Alzheimer's disease is determined by amyloid beta 42. Neurobiol Aging. 2005 Jun;26(6):785-8.

65. Kim J, Basak JM, Holtzman DM. The role of apolipoprotein E in Alzheimer's disease. Neuron. 2009 Aug 13;63(3):287-303.

66. Corder EH, Saunders AM, Risch NJ, et al. Protective effect of apolipoprotein E type 2 allele for late onset Alzheimer disease. Nat Genet. 1994 Jun;7(2):180-4.

67. Wisniewski T, Castano EM, Golabek A, Vogel T, Frangione B. Acceleration of Alzheimer's fibril formation by apolipoprotein $\mathrm{E}$ in vitro. Am J Pathol. 1994 Nov;145(5):1030-5.

68. Ma J, Yee A, Brewer HB, Jr., Das S, Potter H. Amyloid-associated proteins alpha 1-antichymotrypsin and apolipoprotein E promote assembly of Alzheimer beta-protein into filaments. Nature. 1994 Nov 3;372(6501):92-4.

69. Holtzman DM, Bales KR, Tenkova T, et al. Apolipoprotein E isoform-dependent amyloid deposition and neuritic degeneration in a mouse model of Alzheimer's disease. Proc Natl Acad Sci USA. 2000;97(6):2892-7.

70. Schmechel DE, Saunders AM, Strittmatter WJ, et al. Increased amyloid beta-peptide deposition in cerebral cortex as a consequence of apolipoprotein E genotype in late-onset Alzheimer disease. Proc Natl Acad Sci U S A. 1993 Oct 15;90 (20):9649-53.

71. Castellano JM, Kim J, Stewart FR, et al. Human apoE isoforms differentially regulate brain amyloid-beta peptide clearance. Sci Transl Med. 2011 Jun 29;3(89):89ra57.

72. Gatz M, Reynolds CA, Fratiglioni L, et al. Role of genes and environments for explaining Alzheimer disease. Arch Gen Psychiatry. 2006 Feb;63(2):168-74.

73. Bertram L, Lill CM, Tanzi RE. The genetics of Alzheimer disease: back to the future. Neuron. 2010 Oct 21;68(2):270-81.

74. Hollingworth P, Harold D, Sims R, et al. Common variants at ABCA7, MS4A6A/MS4A4E, EPHA1, CD33 and CD2AP are associated with Alzheimer's disease. Nat Genet. 2011 May;43 (5):429-35

75. Naj AC, Jun G, Beecham GW, et al. Common variants at MS4A4/MS4A6E, CD2AP, CD33 and EPHA1 are associated with late-onset Alzheimer's disease. Nat Genet. 2011 May;43(5): 436-41.

76. Belbin O, Carrasquillo MM, Crump M, et al. Investigation of 15 of the top candidate genes for late-onset Alzheimer's disease. Hum Genet. 2011 Mar;129(3):273-82.

77. Bertram L, Tanzi RE. Thirty years of Alzheimer's disease genetics: the implications of systematic meta-analyses. Nat Rev Neurosci. 2008 Oct;9(10):768-78.

78. Gomez-Isla T, Hollister R, West H, et al. Neuronal loss correlates with but exceeds neurofibrillary tangles in Alzheimer's disease. Ann Neurol. 1997 Jan;41(1):17-24.

79. Ballatore C, Lee VM, Trojanowski JQ. Tau-mediated neurodegeneration in Alzheimer's disease and related disorders. Nat Rev Neurosci. 2007 Sep;8(9):663-72.

80. Jacobsen JS, Wu CC, Redwine JM, et al. Early-onset behavioral and synaptic deficits in a mouse model of Alzheimer's disease. Proc Natl Acad Sci USA. 2006 Mar 28;103(13):5161-6.

81. Braak H, Braak E. Neuropathological stageing of Alzheimer-related changes. Acta Neuropathol. 1991;82(4):239-59.

82. van Swieten J, Spillantini MG. Hereditary frontotemporal dementia caused by Tau gene mutations. Brain Pathol. 2007 Jan;17(1): 63-73.

83. Lemere CA, Blusztajn JK, Yamaguchi H, Wisniewski T, Saido TC, Selkoe DJ. Sequence of deposition of heterogeneous amyloid beta-peptides and APO E in Down syndrome: implications for initial events in amyloid plaque formation. Neurobiol Dis. 1996 Feb;3(1):16-32.

84. Oddo S, Caccamo A, Tran L, et al. Temporal profile of amyloid-beta (Abeta) oligomerization in an in vivo model of Alzheimer disease. A link between Abeta and tau pathology. J Biol Chem. 2006 Jan 20;281(3):1599-604.
85. Lewis J, Dickson DW, Lin WL, et al. Enhanced neurofibrillary degeneration in transgenic mice expressing mutant tau and APP. Science. 2001 Aug 24;293(5534):1487-91.

86. Gotz J, Chen F, van Dorpe J, Nitsch RM. Formation of neurofibrillary tangles in P3011 tau transgenic mice induced by Abeta 42 fibrils. Science. 2001 Aug 24;293(5534):1491-5.

87. Oddo S, Billings L, Kesslak JP, Cribbs DH, LaFerla FM. Abeta immunotherapy leads to clearance of early, but not late, hyperphosphorylated tau aggregates via the proteasome. Neuron. 2004 Aug 5;43(3):321-32.

88. Bolmont T, Clavaguera F, Meyer-Luehmann M, et al. Induction of tau pathology by intracerebral infusion of amyloid-beta containing brain extract and by amyloid-beta deposition in APP x Tau transgenic mice. Am J Pathol. 2007 Dec;171(6):2012-20.

89. Santacruz K, Lewis J, Spires T, et al. Tau suppression in a neurodegenerative mouse model improves memory function. Science. 2005 Jul 15;309(5733):476-81

90. Roberson ED, Scearce-Levie K, Palop JJ, et al. Reducing endogenous tau ameliorates amyloid beta-induced deficits in an Alzheimer's disease mouse model. Science. 2007 May 4;316 (5825):750-4.

91. Ittner LM, Ke YD, Delerue F, et al. Dendritic function of tau mediates amyloid-beta toxicity in Alzheimer's disease mouse models. Cell. 2010 Aug 6;142(3):387-97.

92. Terry RD, Masliah E, Salmon DP, et al. Physical basis of cognitive alterations in Alzheimer's disease: synapse loss is the major correlate of cognitive impairment. Ann Neurol. 1991 Oct;30(4): 572-80.

93. Scheff SW, Price DA. Synaptic pathology in Alzheimer's disease: a review of ultrastructural studies. Neurobiol Aging. 2003 Dec;24 (8):1029-46.

94. Scheff SW, Price DA, Schmitt FA, DeKosky ST, Mufson EJ. Synaptic alterations in CA1 in mild Alzheimer disease and mild cognitive impairment. Neurology. 2007 May 1;68(18):1501-8.

95. Selkoe DJ. Alzheimer's disease is a synaptic failure. Science. 2002 Oct 25;298(5594):789-91

96. Naslund J, Haroutunian V, Mohs R, et al. Correlation between elevated levels of amyloid beta-peptide in the brain and cognitive decline. JAMA. 2000 Mar 22-29;283(12):1571-7.

97. Lue LF, Kuo YM, Roher AE, et al. Soluble amyloid beta peptide concentration as a predictor of synaptic change in Alzheimer's disease. Am J Pathol. 1999 Sep;155(3):853-62.

98. Walsh DM, Selkoe DJ. A beta oligomers - a decade of discovery. J Neurochem. 2007 Jun;101(5):1172-84.

99. Lacor PN, Buniel MC, Furlow PW, et al. Abeta oligomer-induced aberrations in synapse composition, shape, and density provide a molecular basis for loss of connectivity in Alzheimer's disease. J Neurosci. 2007 Jan 24;27(4):796-807.

100. Lesne S, Koh MT, Kotilinek L, et al. A specific amyloid-beta protein assembly in the brain impairs memory. Nature. 2006 Mar 16;440(7082):352-7.

101. Shankar GM, Li S, Mehta TH, et al. Amyloid-beta protein dimers isolated directly from Alzheimer's brains impair synaptic plasticity and memory. Nat Med. 2008 Aug;14(8):837-42.

102. Cleary JP, Walsh DM, Hofmeister JJ, et al. Natural oligomers of the amyloid-beta protein specifically disrupt cognitive function. Nat Neurosci. 2005 Jan;8(1):79-84

103. Shankar GM, Bloodgood BL, Townsend M, Walsh DM, Selkoe DJ, Sabatini BL. Natural oligomers of the Alzheimer amyloid-beta protein induce reversible synapse loss by modulating an NMDA-type glutamate receptor-dependent signaling pathway. J Neurosci. 2007 Mar 14:27(11):2866-75.

104. Dodart JC, Bales KR, Gannon KS, et al. Immunization reverses memory deficits without reducing brain Abeta burden in Alzheimer's disease model. Nat Neurosci. 2002 May;5(5):452-7.

105. Balducci C, Beeg M, Stravalaci M, et al. Synthetic amyloid-beta oligomers impair long-term memory independently of cellular prion protein. Proc Natl Acad Sci USA. 2010 Feb 2;107(5): 2295-300.

106. Bell KF, Ducatenzeiler A, Ribeiro-da-Silva A, Duff K, Bennett DA, Cuello AC. The amyloid pathology progresses in a neurotransmitter-specific manner. Neurobiol Aging. 2006 Nov; 27(11):1644-57. 
107. Renner M, Lacor PN, Velasco PT, et al. Deleterious effects of amyloid beta oligomers acting as an extracellular scaffold for mGluR5. Neuron. Jun 10;66(5):739-54.

108. Parodi J, Sepulveda FJ, Roa J, Opazo C, Inestrosa NC, Aguayo LG. Beta-amyloid causes depletion of synaptic vesicles leading to neurotransmission failure. J Biol Chem. Jan 22;285(4):2506-14.

109. Lauren J, Gimbel DA, Nygaard HB, Gilbert JW, Strittmatter SM. Cellular prion protein mediates impairment of synaptic plasticity by amyloid-beta oligomers. Nature. 2009 Feb 26;457(7233): 1128-32.

110. Barry AE, Klyubin I, Mc Donald JM, et al. Alzheimer's disease brain-derived amyloid-beta-mediated inhibition of LTP in vivo is prevented by immunotargeting cellular prion protein. J Neurosci. 2011 May 18;31(20):7259-63.

111. Gimbel DA, Nygaard HB, Coffey EE, et al. Memory impairment in transgenic Alzheimer mice requires cellular prion protein. J Neurosci. 2010 May 5;30(18):6367-74.

112. Calella AM, Farinelli M, Nuvolone M, et al. Prion protein and Abeta-related synaptic toxicity impairment. EMBO Mol Med. Aug;2(8):306-14.

113. Dunn WA, Jr. Studies on the mechanisms of autophagy: maturation of the autophagic vacuole. J Cell Biol. 1990 Jun;110(6):1935-45.

114. Dunn WA, Jr. Studies on the mechanisms of autophagy: formation of the autophagic vacuole. J Cell Biol. 1990 Jun;110(6):1923-33.

115. Nixon RA, Cataldo AM, Mathews PM. The endosomal-lysosomal system of neurons in Alzheimer's disease pathogenesis: a review. Neurochem Res. 2000;25(9-10):1161-72.

116. Eskelinen EL, Tanaka Y, Saftig P. At the acidic edge: emerging functions for lysosomal membrane proteins. Trends Cell Biol. 2003 Mar;13(3):137-45.

117. Sachse M, Ramm G, Strous G, Klumperman J. Endosomes: multipurpose designs for integrating housekeeping and specialized tasks. Histochem Cell Biol. 2002 Feb;117(2):91-104.

118. Pillay CS, Elliott E, Dennison C. Endolysosomal proteolysis and its regulation. Biochem J. 2002 May 1;363(Pt 3):417-29.

119. Li AX, Hudson RHE, Barrett JW, Jones CK, Pasternak SH, Bartha R. Four-pool modeling of proton exchange processes in biological systems in the presence of MRI-paramagnetic chemical exchange saturation transfer (PARACEST) agents. Magn Reson Med. 2008;60(5):1197-206.

120. Jaiswal JK, Andrews NW, Simon SM. Membrane proximal lysosomes are the major vesicles responsible for calciumdependent exocytosis in nonsecretory cells. J Cell Biol. 2002 Nov 25;159(4):625-35.

121. Stinchcombe JC, Griffiths GM. Regulated secretion from hemopoietic cells. J Cell Biol. 1999 Oct 4;147(1):1-6.

122. Andrews NW. Regulated secretion of conventional lysosomes. Trends Cell Biol. 2000;10(8):316-21.

123. Reddy A, Caler EV, Andrews NW. Plasma membrane repair is mediated by $\mathrm{Ca}(2+)$-regulated exocytosis of lysosomes. Cell. 2001;106(2):157-69.

124. Haass C, Koo EH, Mellon A, Hung AY, Selkoe DJ. Targeting of cell-surface beta-amyloid precursor protein to lysosomes: alternative processing into amyloid-bearing fragments. Nature. 1992;357(6378):500-3.

125. Koo EH, Squazzo SL. Evidence that production and release of amyloid beta-protein involves the endocytic pathway. J Biol Chem. 1994;269(26): 17386-9.

126. Koo EH, Squazzo SL, Selkoe DJ, Koo CH. Trafficking of cellsurface amyloid beta-protein precursor. I. Secretion, endocytosis and recycling as detected by labeled monoclonal antibody. J Cell Sci. 1996;109(Pt 5):991-8.

127. Yamazaki T, Koo EH, Selkoe DJ. Trafficking of cell-surface amyloid beta-protein precursor. II. Endocytosis, recycling and lysosomal targeting detected by immunolocalization. J Cell Sci. 1996;109(Pt 5):999-1008.

128. Jung SS, Cashman NR. Processing of the beta-amyloid precursor protein in ex vivo human brain cells. Neuroreport. 1999;10(18): 3875-9.

129. Grbovic OM, Mathews PM, Jiang Y, et al. Rab5-stimulated upregulation of the endocytic pathway increases intracellular betacleaved amyloid precursor protein carboxyl-terminal fragment levels and Abeta production. J Biol Chem. 2003 Aug 15;278 (33):31261-8

130. Colombo A, Bastone A, Ploia C, et al. JNK regulates APP cleavage and degradation in a model of Alzheimer's disease. Neurobiol Dis. 2009 Mar;33(3):518-25.

131. Vieira SI, Rebelo S, Domingues SC, da Cruz e Silva EF, da Cruz e Silva OA. S655 phosphorylation enhances APP secretory traffic. Mol Cell Biochem. 2009 Aug;328(1-2):145-54.

132. Rebelo S, Vieira SI, Esselmann H, Wiltfang J, da Cruz e Silva EF, da Cruz e Silva OA. Tyr687 dependent APP endocytosis and Abeta production. J Mol Neurosci. 2007;32(1):1-8.

133. Rebelo S, Vieira SI, Esselmann H, Wiltfang J, da Cruz e Silva EF, da Cruz e Silva OA. Tyrosine 687 phosphorylated Alzheimer's amyloid precursor protein is retained intracellularly and exhibits a decreased turnover rate. Neurodegener Dis. 2007;4(2-3):78-87.

134. Suzuki T, Nakaya T. Regulation of amyloid beta-protein precursor by phosphorylation and protein interactions. J Biol Chem. 2008 Oct 31;283(44):29633-7.

135. Schobel S, Neumann S, Hertweck M, et al. A novel sorting nexin modulates endocytic trafficking and alpha-secretase cleavage of the amyloid precursor protein. J Biol Chem. 2008 May 23;283 (21): $14257-68$

136. Schobel S, Neumann S, Seed B, Lichtenthaler SF. Expression cloning screen for modifiers of amyloid precursor protein shedding. Int J Dev Neurosci. 2006 Apr-May;24(2-3):141-8.

137. Miller CC, McLoughlin DM, Lau KF, Tennant ME, Rogelj B. The X11 proteins, Abeta production and Alzheimer's disease. Trends Neurosci. 2006 May;29(5):280-5.

138. Yu WH, Cuervo AM, Kumar A, et al. Macroautophagy--a novel \{beta\}-amyloid peptide-generating pathway activated in Alzheimer's disease. J Cell Biol. 2005 Oct 10;171(1):87-98.

139. Yu WH, Kumar A, Peterhoff C, et al. Autophagic vacuoles are enriched in amyloid precursor protein-secretase activities: implications for beta-amyloid peptide over-production and localization in Alzheimer's disease. Int J Biochem Cell Biol. 2004 Dec;36(12):2531-40.

140. Bagshaw RD, Pasternak SH, Mahuran DJ, Callahan JW. Nicastrin is a resident lysosomal membrane protein. Biochem Biophys Res Commun. 2003 Jan 17:300(3):615-18.

141. Pasternak SH, Bagshaw RD, Guiral M, et al. Presenilin-1, nicastrin, amyloid precursor protein, and gamma-secretase activity are colocalized in the lysosomal membrane. J Biol Chem. 2003 Jul 18; 278(29):26687-94.

142.Lorenzen A, Samosh J, Vandewark K, et al. Rapid and direct transport of cell surface APP to the lysosome defines a novel selective pathway. Mol Brain. 2010;3:11.

143. Pasternak SH, Callahan JW, Mahuran DJ. The role of the endosomal/lysosomal system in amyloid-beta production and the pathophysiology of Alzheimer's disease: reexamining the spatial paradox from a lysosomal perspective. J Alzheimers Dis. $2004 \mathrm{Feb} ; 6(1): 53-65$.

144. Turner RS, Suzuki N, Chyung AS, Younkin SG, Lee VM. Amyloids beta40 and beta42 are generated intracellularly in cultured human neurons and their secretion increases with maturation. J Biol Chem. 1996;271(15):8966-70.

145. Wertkin AM, Turner RS, Pleasure SJ, et al. Human neurons derived from a teratocarcinoma cell line express solely the 695-amino acid amyloid precursor protein and produce intracellular betaamyloid or A4 peptides. Proc Natl Acad Sci USA. 1993 Oct 15; 90(20):9513-17.

146. Martin BL, Schrader-Fischer G, Busciglio J, Duke M, Paganetti P, Yankner BA. Intracellular accumulation of beta-amyloid in cells expressing the Swedish mutant amyloid precursor protein. J Biol Chem. 1995 Nov 10;270(45):26727-30.

147. Skovronsky DM, Doms RW, Lee VM. Detection of a novel intraneuronal pool of insoluble amyloid beta protein that accumulates with time in culture. J Cell Biol. 1998 May 18;141 (4):1031-9.

148. Walsh DM, Tseng BP, Rydel RE, Podlisny MB, Selkoe DJ. The oligomerization of amyloid beta-protein begins intracellularly in cells derived from human brain. Biochemistry. 2000;39(35): 10831-9. 
149.D'Andrea MR, Nagele RG, Wang HY, Peterson PA, Lee DH. Evidence that neurones accumulating amyloid can undergo lysis to form amyloid plaques in Alzheimer's disease. Histopathology. 2001;38(2):120-34.

150. D'Andrea MR, Reiser PA, Polkovitch DA, et al. The use of formic acid to embellish amyloid plaque detection in Alzheimer's disease tissues misguides key observations. Neurosci Lett. 2003 May 15;342(1-2):114-18.

151.D'Andrea MR, Nagele RG, Wang HY, Lee DH. Consistent immunohistochemical detection of intracellular beta-amyloid42 in pyramidal neurons of Alzheimer's disease entorhinal cortex. Neurosci Lett. 2002 Nov 29;333(3):163-6.

152. Aho L, Pikkarainen M, Hiltunen M, Leinonen V, Alafuzoff I. Immunohistochemical visualization of amyloid-beta protein precursor and amyloid-beta in extra- and intracellular compartments in the human brain. J Alzheimers Dis. 2010;20(4): 1015-28.

153. Gouras GK, Tampellini D, Takahashi RH, Capetillo-Zarate E. Intraneuronal beta-amyloid accumulation and synapse pathology in Alzheimer's disease. Acta Neuropathol. 2010 May;119(5): 523-41

154. Winton MJ, Lee EB, Sun E, et al. Intraneuronal APP, not free Abeta peptides in 3xTg-AD mice: implications for tau versus Abetamediated Alzheimer neurodegeneration. J Neurosci. 2011 May 25;31(21):7691-9.

155. Glabe C. Intracellular mechanisms of amyloid accumulation and pathogenesis in Alzheimer's disease. J Mol Neurosci. 2001 Oct; 17(2):137-45.

156. Gouras GK, Almeida CG, Takahashi RH. Intraneuronal Abeta accumulation and origin of plaques in Alzheimer's disease. Neurobiol Aging. 2005 Oct;26(9):1235-44.

157.LaFerla FM, Green KN, Oddo S. Intracellular amyloid-beta in Alzheimer's disease. Nat Rev Neurosci. 2007 Jul;8(7):499-509.

158. Chui DH, Tanahashi H, Ozawa K, et al. Transgenic mice with Alzheimer presenilin 1 mutations show accelerated neurodegeneration without amyloid plaque formation. Nat Med. 1999 May;5(5):560-4

159. Shie FS, LeBoeur RC, Jin LW. Early intraneuronal Abeta deposition in the hippocampus of APP transgenic mice. Neuroreport. 2003 Jan 20;14(1):123-9.

160. Wirths O, Multhaup $\mathrm{G}$, Czech $\mathrm{C}$, et al. Intraneuronal Abeta accumulation precedes plaque formation in beta-amyloid precursor protein and presenilin-1 double-transgenic mice. Neurosci Lett. 2001 Jun 22;306(1-2):116-20.

161. Takahashi RH, Almeida CG, Kearney PF, et al. Oligomerization of Alzheimer's beta-amyloid within processes and synapses of cultured neurons and brain. J Neurosci. 2004 Apr 7;24(14): 3592-9.

162. Knobloch M, Konietzko U, Krebs DC, Nitsch RM. Intracellular Abeta and cognitive deficits precede beta-amyloid deposition in transgenic arcAbeta mice. Neurobiol Aging. 2007 Sep;28(9): 1297-306.

163. Oakley H, Cole SL, Logan S, et al. Intraneuronal beta-amyloid aggregates, neurodegeneration, and neuron loss in transgenic mice with five familial Alzheimer's disease mutations: potential factors in amyloid plaque formation. J Neurosci. 2006 Oct 4;26 (40): $10129-40$

164. Oddo S, Caccamo A, Smith IF, Green KN, LaFerla FM. A dynamic relationship between intracellular and extracellular pools of Abeta. Am J Pathol. 2006 Jan;168(1):184-94.

165. Yan P, Bero AW, Cirrito JR, et al. Characterizing the appearance and growth of amyloid plaques in APP/PS1 mice. J Neurosci. 2009 Aug 26;29(34):10706-14.

166. Billings LM, Oddo S, Green KN, McGaugh JL, Laferla FM. Intraneuronal Abeta causes the onset of early Alzheimer's disease-related cognitive deficits in transgenic mice. Neuron. 2005 Mar 3;45(5):675-88.

167. Gouras GK, Tsai J, Naslund J, et al. Intraneuronal Abeta42 accumulation in human brain. Am J Pathol. 2000;156(1):15-20.

168. Gyure KA, Durham R, Stewart WF, Smialek JE, Troncoso JC. Intraneuronal abeta-amyloid precedes development of amyloid plaques in Down syndrome. Arch Pathol Lab Med. 2001 Apr; 125(4):489-92.
169. Cataldo AM, Petanceska S, Terio NB, et al. Abeta localization in abnormal endosomes: association with earliest Abeta elevations in AD and Down syndrome. Neurobiol Aging. 2004 Nov-Dec; 25(10):1263-72.

170.LaFerla FM, Troncoso JC, Strickland DK, Kawas CH, Jay G. Neuronal cell death in Alzheimer's disease correlates with apoE uptake and intracellular Abeta stabilization. J Clin Invest. 1997 Jul 15;100(2):310-20

171. Aoki M, Volkmann I, Tjernberg LO, Winblad B, Bogdanovic N. Amyloid beta-peptide levels in laser capture microdissected cornu ammonis 1 pyramidal neurons of Alzheimer's brain. Neuroreport. 2008 Jul 16;19(11):1085-9.

172. Hashimoto M, Bogdanovic N, Volkmann I, Aoki M, Winblad B, Tjernberg LO. Analysis of microdissected human neurons by a sensitive ELISA reveals a correlation between elevated intracellular concentrations of Abeta42 and Alzheimer's disease neuropathology. Acta Neuropathol. 2010 May;119(5):543-54.

173. Su Y, Chang PT. Acidic $\mathrm{pH}$ promotes the formation of toxic fibrils from beta-amyloid peptide. Brain Res. 2001;893(1-2):287-91.

174. Inouye H, Kirschner DA. A beta fibrillogenesis: kinetic parameters for fibril formation from congo red binding. J Struct Biol. 2000 Jun;130(2-3):123-9.

175. McLaurin J, Chakrabartty A. Membrane disruption by Alzheimer beta-amyloid peptides mediated through specific binding to either phospholipids or gangliosides. Implications for neurotoxicity. J Biol Chem. 1996 Oct 25;271(43):26482-9.

176. Waschuk SA, Elton EA, Darabie AA, Fraser PE, McLaurin JA. Cellular membrane composition defines A beta-lipid interactions. J Biol Chem. 2001;276(36):33561-8.

177. Yanagisawa K, Odaka A, Suzuki N, Ihara Y. GM1 gangliosidebound amyloid beta-protein (A beta): a possible form of preamyloid in Alzheimer's disease. Nat Med. 1995 Oct;1(10): 1062-6.

178. Yip CM, McLaurin J. Amyloid-beta peptide assembly: a critical step in fibrillogenesis and membrane disruption. Biophys J. 2001;80(3): 1359-71

179. Knauer MF, Soreghan B, Burdick D, Kosmoski J, Glabe CG. Intracellular accumulation and resistance to degradation of the Alzheimer amyloid A4/beta protein. Proc Natl Acad Sci USA. 1992;89(16):7437-41

180. Yang AJ, Knauer M, Burdick DA, Glabe C. Intracellular A beta 142 aggregates stimulate the accumulation of stable, insoluble amyloidogenic fragments of the amyloid precursor protein in transfected cells. J Biol Chem. 1995 Jun 16;270(24):14786-92.

181. Yang AJ, Chandswangbhuvana D, Shu T, Henschen A, Glabe CG. Intracellular accumulation of insoluble, newly synthesized abetan-42 in amyloid precursor protein-transfected cells that have been treated with Abeta1-42. J Biol Chem. 1999;274(29): 20650-6.

182.Hu X, Crick SL, Bu G, Frieden C, Pappu RV, Lee JM. Amyloid seeds formed by cellular uptake, concentration, and aggregation of the amyloid-beta peptide. Proc Natl Acad Sci USA. 2009 Dec 1;106(48):20324-9.

183. Takahashi RH, Milner TA, Li F, et al. Intraneuronal Alzheimer abeta42 accumulates in multivesicular bodies and is associated with synaptic pathology. Am J Pathol. 2002 Nov;161(5): 1869-79.

184. Yang AJ, Chandswangbhuvana D, Margol L, Glabe CG. Loss of endosomal/lysosomal membrane impermeability is an early event in amyloid Abeta1-42 pathogenesis. J Neurosci Res. 1998; 52(6):691-8.

185.Ji ZS, Miranda RD, Newhouse YM, Weisgraber KH, Huang Y, Mahley RW. Apolipoprotein E4 potentiates amyloid beta peptide-induced lysosomal leakage and apoptosis in neuronal cells. J Biol Chem. 2002 Jun 14;277(24):21821-8.

186. Turk B, Turk V. Lysosomes as "suicide bags" in cell death: myth or reality? J Biol Chem. 2009 Aug 14;284(33):21783-7.

187. Kienlen-Campard P, Miolet S, Tasiaux B, Octave JN. Intracellular amyloid-beta 1-42, but not extracellular soluble amyloid-beta peptides, induces neuronal apoptosis. J Biol Chem. 2002 May 3; 277(18):15666-70

188. Mori C, Spooner ET, Wisniewsk KE, et al. Intraneuronal Abeta42 accumulation in Down syndrome brain. Amyloid. 2002 Jun;9(2): 88-102. 
189. Cataldo AM, Nixon RA. Enzymatically active lysosomal proteases are associated with amyloid deposits in Alzheimer brain. Proc Natl Acad Sci USA. 1990 May;87(10):3861-5.

190. Cataldo AM, Paskevich PA, Kominami E, Nixon RA. Lysosomal hydrolases of different classes are abnormally distributed in brains of patients with Alzheimer disease. Proc Natl Acad Sci USA. 1991 Dec 15;88(24):10998-1002.

191. Cataldo AM, Hamilton DJ, Nixon RA. Lysosomal abnormalities in degenerating neurons link neuronal compromise to senile plaque development in Alzheimer disease. Brain Res. 1994 Mar 21;640 (1-2):68-80.

192. Mach L. Biosynthesis of lysosomal proteinases in health and disease. Biol Chem. 2002 May;383(5):751-6.

193. D'Andrea M, Nagele R. Morphologically distinct types of amyloid plaques point the way to a better understanding of Alzheimer's disease pathogenesis. Biotech Histochem. 2010 Apr;85(2): $133-47$.

194. Meyer-Luehmann M, Spires-Jones TL, Prada C, et al. Rapid appearance and local toxicity of amyloid-beta plaques in a mouse model of Alzheimer's disease. Nature. 2008 Feb 7;451 (7179):720-4.

195. Cataldo AM, Barnett JL, Pieroni C, Nixon RA. Increased neuronal endocytosis and protease delivery to early endosomes in sporadic Alzheimer's disease: neuropathologic evidence for a mechanism of increased beta-amyloidogenesis. J Neurosci. 1997;17(16):6142-51.

196. Cataldo AM, Peterhoff CM, Troncoso JC, Gomez-Isla T, Hyman BT, Nixon RA. Endocytic pathway abnormalities precede amyloid beta deposition in sporadic Alzheimer's disease and Down syndrome: differential effects of APOE genotype and presenilin mutations. Am J Pathol. 2000;157(1):277-86.

197. Cataldo AM, Peterhoff CM, Schmidt SD, et al. Presenilin mutations in familial Alzheimer disease and transgenic mouse models accelerate neuronal lysosomal pathology. J Neuropathol Exp Neurol. 2004 Aug;63(8):821-30.

198. Nixon RA, Wegiel J, Kumar A, et al. Extensive involvement of autophagy in Alzheimer disease: an immuno-electron microscopy study. J Neuropathol Exp Neurol. 2005 Feb;64(2): 113-22.

199. Nixon RA, Yang DS, Lee JH. Neurodegenerative lysosomal disorders: a continuum from development to late age. Autophagy. 2008 Jul 1;4(5):590-9.

200. Boland B, Kumar A, Lee S, et al. Autophagy induction and autophagosome clearance in neurons: relationship to autophagic pathology in Alzheimer's disease. J Neurosci. 2008 Jul 2;28(27): 6926-37.

201.Komatsu M, Waguri S, Chiba T, et al. Loss of autophagy in the central nervous system causes neurodegeneration in mice. Nature. 2006 Jun 15;441(7095):880-4.

202. Yamazaki T, Chang TY, Haass C, Ihara Y. Accumulation and aggregation of amyloid beta-protein in late endosomes of Niemann-pick type C cells. J Biol Chem. 2001;276(6):4454-60.

203. Boland B, Smith DA, Mooney D, Jung SS, Walsh DM, Platt FM. Macroautophagy is not directly involved in the metabolism of amyloid precursor protein. J Biol Chem. 2010 Nov 26;285 (48): 37415-26.

204.Ginsberg SD, Galvin JE, Lee VM, et al. Accumulation of intracellular amyloid-beta peptide (A beta 1-40) in mucopolysaccharidosis brains. J Neuropathol Exp Neurol. 1999 Aug;58(8):815-24.

205. Lee S, Sato Y, Nixon RA. Lysosomal proteolysis inhibition selectively disrupts axonal transport of degradative organelles and causes an Alzheimer's-like axonal dystrophy. J Neurosci. 2011 May 25;31(21):7817-30.

206. Tamboli IY, Hampel H, Tien NT, et al. Sphingolipid storage affects autophagic metabolism of the amyloid precursor protein and promotes Abeta generation. J Neurosci. 2011 Feb 2;31(5): $1837-49$.

207.Zhang M, Haapasalo A, Kim DY, Ingano LA, Pettingell WH, Kovacs DM. Presenilin/gamma-secretase activity regulates protein clearance from the endocytic recycling compartment. FASEB J. 2006 Jun;20(8):1176-8.
208. Bagshaw R, Pasternak S, Mahuran D, Callahan J. Nicastrin is a resident lysosomal membrane protein. Biochem Bioph Res Co. 2003 Jan 17 2003;300(3):615-18

209. Neely KM, Green KN, LaFerla FM. Presenilin is necessary for efficient proteolysis through the autophagy-lysosome system in a gamma-secretase-independent manner. J Neurosci. 2011 Feb 23;31(8):2781-91.

210. Hryciw T, MacDonald JIS, Phillips R, Seah C, Pasternak S, Meakin $\mathrm{SO}$. The fibroblast growth factor receptor substrate 3 adapter is a developmentally regulated microtubule-associated protein expressed in migrating and differentiated neurons. J Neurochem. 2010;112(4):924-39.

211. Lee JH, Yu WH, Kumar A, et al. Lysosomal proteolysis and autophagy require presenilin 1 and are disrupted by Alzheimerrelated PS1 mutations. Cell. 2010 Jun 25;141(7):1146-58.

212. Yang DS, Stavrides P, Mohan PS, et al. Reversal of autophagy dysfunction in the TgCRND8 mouse model of Alzheimer's disease ameliorates amyloid pathologies and memory deficits. Brain. 2010 Jan;134(Pt 1):258-77.

213. Butler D, Brown QB, Chin DJ, et al. Cellular responses to protein accumulation involve autophagy and lysosomal enzyme activation. Rejuvenation Res. 2005 Winter;8(4):227-37.

214. Bendiske J, Bahr BA. Lysosomal activation is a compensatory response against protein accumulation and associated synaptopathogenesis--an approach for slowing Alzheimer disease? J Neuropathol Exp Neurol. 2003 May;62(5):451-63.

215. Golde TE, Petrucelli L, Lewis J. Targeting Abeta and tau in Alzheimer's disease, an early interim report. Exp Neurol. 2010 Jun;223(2):252-66.

216. Mangialasche F, Solomon A, Winblad B, Mecocci P, Kivipelto M. Alzheimer's disease: clinical trials and drug development. Lancet Neurol. 2010 Jul;9(7):702-16.

217. Salloway S, Sperling R, Gilman S, et al. A phase 2 multiple ascending dose trial of bapineuzumab in mild to moderate Alzheimer disease. Neurology. 2009 Dec 15;73(24):2061-70.

218. Rinne JO, Brooks DJ, Rossor MN, et al. 11C-PiB PET assessment of change in fibrillar amyloid-beta load in patients with Alzheimer's disease treated with bapineuzumab: a phase 2, double-blind, placebo-controlled, ascending-dose study. Lancet Neurol. 2010 Apr;9(4):363-72.

219. Istrin G, Bosis E, Solomon B. Intravenous immunoglobulin enhances the clearance of fibrillar amyloid-beta peptide. J Neurosci Res. 2006 Aug 1;84(2):434-43.

220. Banks WA, Farr SA, Morley JE, Wolf KM, Geylis V, Steinitz M. Anti-amyloid beta protein antibody passage across the bloodbrain barrier in the SAMP8 mouse model of Alzheimer's disease: an age-related selective uptake with reversal of learning impairment. Exp Neurol. 2007 Aug;206(2):248-56.

221. Dodel RC, Du Y, Depboylu C, et al. Intravenous immunoglobulins containing antibodies against beta-amyloid for the treatment of Alzheimer's disease. J Neurol Neurosurg Psychiatry. 2004 Oct; 75(10):1472-4

222. Relkin NR, Szabo P, Adamiak B, et al. 18-Month study of intravenous immunoglobulin for treatment of mild Alzheimer disease. Neurobiol Aging. 2009 Nov;30(11):1728-36.

223. McLaurin J, Kierstead ME, Brown ME, et al. Cyclohexanehexol inhibitors of Abeta aggregation prevent and reverse Alzheimer phenotype in a mouse model. Nat Med. $2006 \mathrm{Jul} ; 12(7): 801-8$.

224. Golde TE, Schneider LS, Koo EH. Anti-abeta therapeutics in Alzheimer's disease: the need for a paradigm shift. Neuron. 2011 Jan 27;69(2):203-13

225. Gilman S, Koller M, Black RS, et al. Clinical effects of Abeta immunization (AN1792) in patients with AD in an interrupted trial. Neurology. 2005 May 10;64(9):1553-62.

226. Nicoll JA, Barton E, Boche D, et al. Abeta species removal after abeta42 immunization. J Neuropathol Exp Neurol. 2006 Nov;65 (11): 1040-8.

227. Sperling RA, Aisen PS, Beckett LA, et al. Toward defining the preclinical stages of Alzheimer's disease: recommendations from the National Institute on Aging-Alzheimer's Association workgroups on diagnostic guidelines for Alzheimer's disease. Alzheimers Dement. 2011 May;7(3):280-92. 
228.Perrin RJ, Fagan AM, Holtzman DM. Multimodal techniques for diagnosis and prognosis of Alzheimer's disease. Nature. 2009 Oct 15;461(7266):916-22.

229. Price JL, McKeel DW, Jr., Buckles VD, et al. Neuropathology of nondemented aging: presumptive evidence for preclinical Alzheimer disease. Neurobiol Aging. 2009 Jul;30(7):1026-36.

230. Mondadori CR, Buchmann A, Mustovic H, et al. Enhanced brain activity may precede the diagnosis of Alzheimer's disease by 30 years. Brain. 2006 Nov;129(Pt 11):2908-22.

231. Knight WD, Kim LG, Douiri A, Frost C, Rossor MN, Fox NC. Acceleration of cortical thinning in familial Alzheimer's disease. Neurobiol Aging. 2011 Oct;32(10):1765-73.

232.Ridha BH, Barnes J, Bartlett JW, et al. Tracking atrophy progression in familial Alzheimer's disease: a serial MRI study. Lancet Neurol. 2006 Oct;5(10):828-34.

233. Gomez-Isla T, Price JL, McKeel DW, Jr., Morris JC, Growdon JH, Hyman BT. Profound loss of layer II entorhinal cortex neurons occurs in very mild Alzheimer's disease. J Neurosci. 1996 Jul 15; 16(14):4491-500.

234. West MJ, Kawas CH, Stewart WF, Rudow GL, Troncoso JC. Hippocampal neurons in pre-clinical Alzheimer's disease. Neurobiol Aging. 2004 Oct;25(9):1205-12.

235. Jack CR, Jr., Albert MS, Knopman DS, et al. Introduction to the recommendations from the National Institute on AgingAlzheimer's Association workgroups on diagnostic guidelines for Alzheimer's disease. Alzheimers Dement. 2011 May;7(3): 257-62.
236. Jack CR, Jr., Knopman DS, Jagust WJ, et al. Hypothetical model of dynamic biomarkers of the Alzheimer's pathological cascade. Lancet Neurol. 2010 Jan;9(1):119-28.

237. Jack CR, Jr., Lowe VJ, Weigand SD, et al. Serial PIB and MRI in normal, mild cognitive impairment and Alzheimer's disease: implications for sequence of pathological events in Alzheimer's disease. Brain. 2009 May;132(Pt 5):1355-65.

238. Heister D, Brewer JB, Magda S, Blennow K, McEvoy LK. Predicting MCI outcome with clinically available MRI and CSF biomarkers. Neurology. 2011 Oct 25;77(17):1619-28.

239. Kalback W, Watson MD, Kokjohn TA, et al. APP transgenic mice Tg2576 accumulate Abeta peptides that are distinct from the chemically modified and insoluble peptides deposited in Alzheimer's disease senile plaques. Biochemistry. 2002 Jan 22; 41(3):922-8.

240. Shen J, Bronson RT, Chen DF, Xia W, Selkoe DJ, Tonegawa S. Skeletal and CNS defects in Presenilin-1-deficient mice. Cell. 1997 May 16;89(4):629-39.

241. Selkoe D, Kopan R. Notch and Presenilin: regulated intramembrane proteolysis links development and degeneration. Annu Rev Neurosci. 2003;26:565-97.

242. Wong GT, Manfra D, Poulet FM, et al. Chronic treatment with the gamma-secretase inhibitor LY-411,575 inhibits beta-amyloid peptide production and alters lymphopoiesis and intestinal cell differentiation. J Biol Chem. 2004 Mar 26;279(13):12876-82. 